\title{
FROM THE ASTONISHED SPECTATOR TO THE SPECTATOR IN MOVEMENT: EXHIBITION ADVERTISEMENTS \\ IN 1920 S GERMANY AND AUSTRIA
}

\begin{abstract}
Résumé : Lorsque les foires commerciales, phénomène nouveau et en voie de professionnalisation, se sont répandues après la première guerre mondiale dans des villes telles que Vienne, Francfort, Berlin et Düsseldorf, elles se sont souvent tournées vers le film comme moyen publicitaire, employant fréquemment des experts en animation ou des cinéastes d'avant-garde. En examinant les films publicitaires faits pour ces évènements, cet essai explore quelques unes des relations changeantes, dans les années 1920, entre le cinéma et la culture des foires commerciales. Les films adoptent souvent une stratégie de l'étonnement qui est commune à la publicité imprimée, aux expositions technologiques du $19^{\text {ième }}$ siècle et au cinéma d'attraction des premiers temps. Mais, ils tendent aussi à illustrer un nouveau paradigme du film comme médium qui peut à la fois interpeler le spectateur et le contrôler. Cette idée du film comme moyen de direction du spectateur est en phase avec les nouvelles théories de la publicité qui sont apparues après la guerre et qui ont trouvé leur terrain d'essai précisément dans le milieu des foires commerciales.
\end{abstract}

$\mathbf{T}$ he image of a motionless spectator seated before a fixed screen once formed an unquestioned axiom of most film theory and history, but few today would see this as the only or even dominant model of spectatorship. The proliferation of mobile screens in the digital age, along with several decades of research into early forms of peripatetic spectatorship (the flâneur, the detective, pre-cinematic forms of urban spectacle, etc.), have attuned film scholars to other, more dynamic modalities of film reception. This attention to mobile audiences has been particularly pronounced in research on exhibitions. In part-and particularly in scholarship focused on film and video installations-the meeting of film and exhibition culture might appear as a new phenomenon. Dominique Païni thus famously argued that the migration of experimental film into galleries since the 1980s had liberated cinema audiences from their "frontal captivity," reviving the experience of the $19^{\text {th }}$-century flâneur and making the spectator-now free to move through the exhibition at his or her own tempo-an active contributor to the filmic experience. ${ }^{1}$ But while some scholars have insisted on the unprecedented nature of film's recent presence in the museum, ${ }^{2}$ other film historians have documented a much longer history of the multiple imbrications between film, 


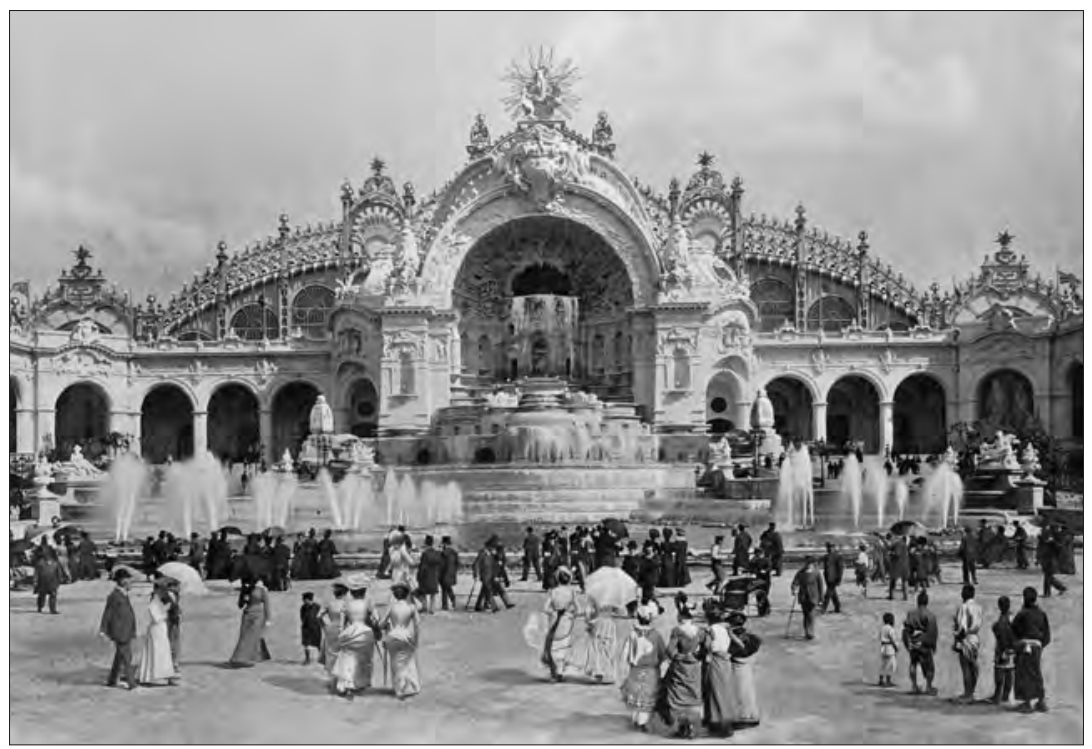

Palace of Electricity at the 1900 Paris World Fair

museums, and exhibitions. ${ }^{3}$ As historians of early cinema have argued, moreover, the cinema itself was no less influenced, in its very emergence, by $19^{\text {th }}$-century exhibition culture. While this included popular forms such as vaudeville and wax museums, it also included "higher" forms such as the universal exhibitions which, as Tom Gunning has shown, helped to inculcate a mode of astonished spectatorship that would help to set the stage, alongside variety culture and scientific illustrations, for the cinema of attractions.

As showcases for industrial progress, the universal exhibitions, with their emphasis on novelty and their future orientation, clearly differed from the institution of the museum as a safeguard of high culture and heritage. Rather than taking objects out of circulation to imbue them with aesthetic value, universal exhibitions displayed objects as prototypes for capitalist circulation. This futureoriented status helps to explain why, with few exceptions, one finds no avantgarde campaign against trade and technology exhibitions remotely comparable to the modernist critiques of the museum. ${ }^{5}$ On the contrary, avant-garde artists from Hans Richter to Herbert Bayer to El Lissitzky readily collaborated with exhibitions and industrial fairs, where they found ample opportunities to experiment with new forms of dynamic and kinetic reception. ${ }^{6}$ On account of this emphasis on novelty and dynamism, technology and trade exhibitions have long functioned as important arenas for the elaboration of more mobile forms of filmic reception. In this article, I want to examine some of the imbrications between film and exhibitions conceived as two technologies for eliciting and directing the movement of spectators and consumers. I will do so by focusing attention on a specific film genre that developed in the German-speaking world in the 1920s: the exhibition advertisement. Although commissioned as advertisements for specific exhibitions, 
these films, I argue, also thematized and worked through changing models of advertising and advertising spectatorship.

Beginning just after WWI, one can find numerous publicity films intended as advertisements for trade and technology exhibitions in cities like Vienna, Berlin, and Basel. Well-known examples include Guido Seeber's advertisement for the 1925 Kipho exhibition of film and photography industries and Richter's Die neue Wohnung (1930), an advertisement for the Werkbund architecture exhibition in Basel. ${ }^{7}$ But there were also many other advertisements by well-known animators of the time such as Peter Eng, Hans Fischerkoesen, and Walter Ruttmann. While the proliferation of such advertisements in the 1920s attests to the appeal that exhibitions had for experimental filmmakers generally, they should also be seen as the result of broader institutional factors. On the one hand, this was the period in which film advertising itself came into its own as an industry; while individual entrepreneurs such as Julius Pinschewer had begun to develop the art of film advertising in the years before the war, the post-war period oversaw a massive expansion of advertising film production and distribution. ${ }^{8}$ On the other hand, there was also a thoroughgoing professionalization of exhibition culture itself. While the trade exhibitions of the 1920s can be seen as descendants of the great $19^{\text {th }}$-century exhibitions of Paris and London, they also had roots in the more time-honoured trade fairs in cities like Lyon, Frankfurt, Milan, Brussels, Barcelona, Vienna, and Leipzig. Such fairs had often operated since Medieval and early modern times, resembling popular markets that coincided with festival periods. But the era of high-capitalist standardization oversaw their transformation (beginning with Leipzig in 1895) into industrial affairs known as Mustermessen, where industries displayed prototypes (Muster) of mass-produced products for separate ordering. ${ }^{9}$ During and after the war years, these industrial fairs also vied to become centers of international trade as traditional fairs were rebranded to emphasize their international status (e.g. the "Frankfurter Internationale Messe" or FIM, renamed in 1919) and others were newly founded (such as the Basel Mustermesse founded in 1916 and the Wiener Internationale Messe [WIM] founded in 1921)..$^{10}$

It was this newly industrialized trade fair that lay behind the phenomenon of the exhibition advertisement. Having established the trade fairs as new focal points of industry, the organizers of the fairs also worked hard to professionalize their image, designing new trademarks and regularly commissioning advertisements in print and film. Examining such film advertisements here, this article traces a shift in the relation between film advertising and exhibition culture in the 1920s, and above all in the model of spectatorship that both practices were working through. As I will show, while such advertisements drew on techniques for managing astonishment familiar from $19^{\text {th }}$-century exhibitions and the cinema of attractions, they increasingly represented both film and the exhibition as two technologies for eliciting and controlling the movement of bodies and attention in a new context of Fordist capitalism.

As practices that helped to shape the experience of novelty under industrial capitalism, the great universal exhibitions of the $19^{\text {th }}$ century were fundamentally 
Poster for the 1922 Frankfurter Internationale Messe (FIM) with newly designed trademark

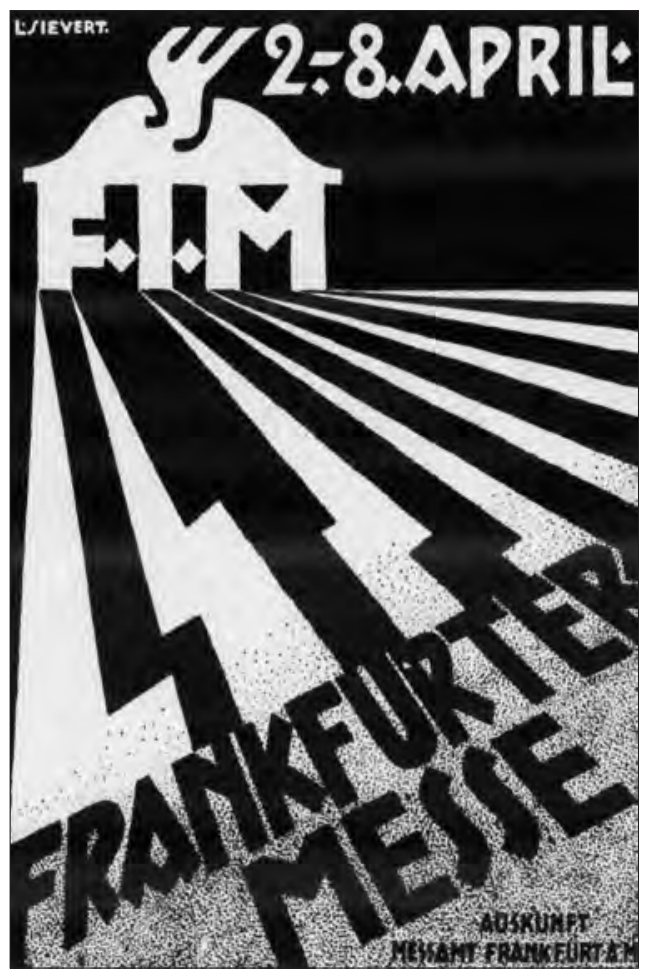

concerned with the interactions between astonishment and familiarity. More precisely, as Gunning has shown, they introduced modes of managing astonishment that would define spectatorship for decades to come. While the interaction of dazzling displays and textual elements "cued spectators" to experience astonishment, the disposition of architecture and attractions also channelled that astonishment into fetishistic displays of technology and commodities, and ultimately into acts of consumption. ${ }^{11}$ At the same time, Gunning is at pains to point out that such displays were not exhausted by their economic function, as they tapped into (even while disavowing) a more deep-seated, "uncanny" capacity for magic, one that "crouches beneath a rational cover, ready to spring out again." 12 It was precisely this secondlevel astonishment that drove the many surrealist appropriations of outworn commodities which, stripped of their economical function, could serve as catalysts for the subversion of economic rationality.

As dress rehearsals for the management of wonder under capitalism, the universal exhibitions of the $19^{\text {th }}$ century clearly influenced the dynamics of advertising, and it is no coincidence that early advertising film adopted similar strategies for eliciting and managing astonishment. Indeed, at the very moment that mainstream cinema was being narrativized in the 1910s and 1920s, advertising films such as those of Pinschewer overwhelmingly privileged an aesthetic of magical attractions derived from Méliès, where magicians and sorcerers 


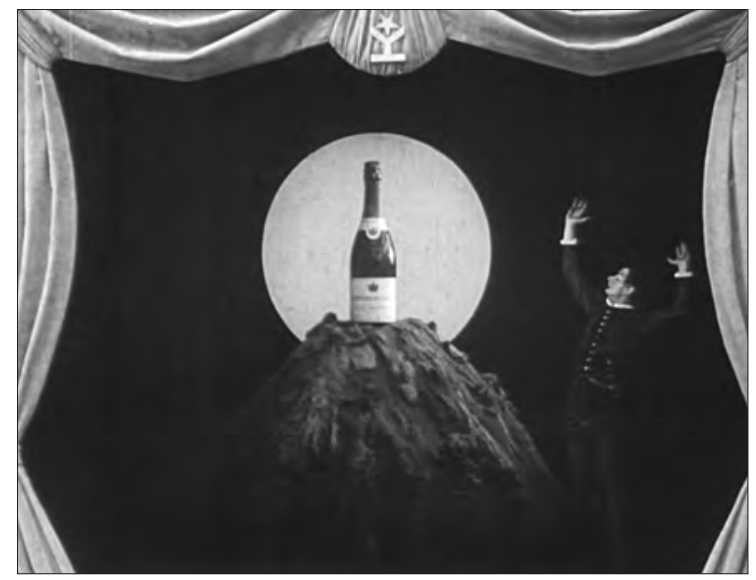

Still from

Julius Pinschewer's

Sektzauber (1912)

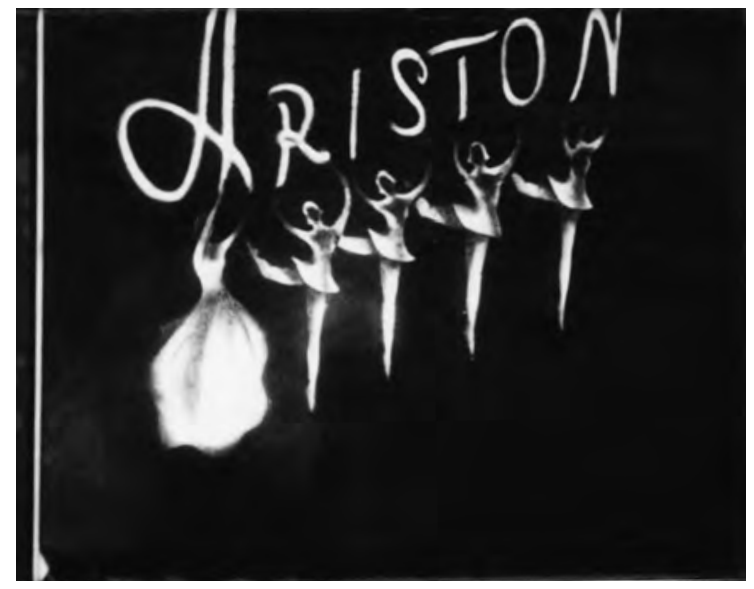

Still from

Hans Fischerkoesen's

Schall und Rauch (1933)

brought commodities to life via stop-motion animation. From the dancing bottles of Pinschewer's commercials for Kupferberg champagne and Maggi sauces (Tanz der Flaschen, 1912) to the many dancing cigarettes of commercials such as Hans Fischerkoesen's Schall und Rauch (Sound and Smoke, 1933) and Oskar Fischinger's Muratti greift ein (Muratti Intervenes, 1934), advertising films in the 1920s are full of uncanny objects: commodity automatons imbued with human-like powers but astonishing us with their seeming independence from human agency. Such representations, moreover, had direct counterparts in product trade fairs, which constantly featured larger-than-life products such as the giant cigarette packages and armies of marching cigarettes. ${ }^{13}$ Crucially, however, both the trade fairs and advertising films were constantly at pains to channel their magical displays towards the useful ends of capitalist consumption.

As exhibition advertisements first arose in the early 1920s, they adopted similar strategies of both evoking and managing astonishment, but they did so 
Ambulatory cigarette advertisement at the Frankfurter Internationale Messe (1920)

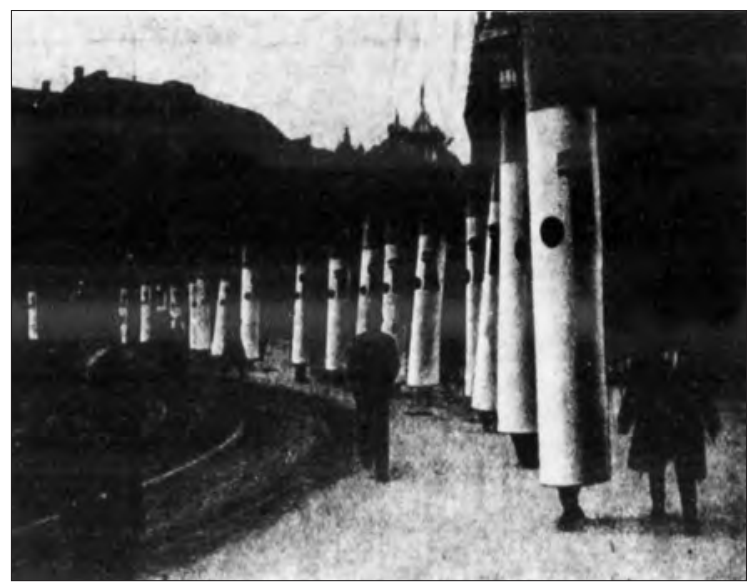

Still from Die Entdeckung Wiens am Nordpol (Peter Eng, 1923)

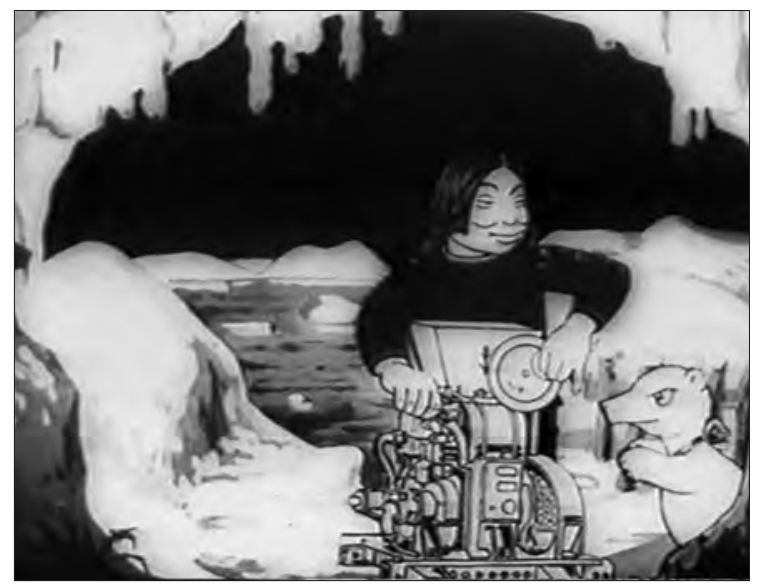

by focusing on the figure of the spectator-consumer and his sense of magical wonder before the exhibition displays. To this end, they frequently adopted what was by then a well-tried strategy for simultaneously evoking and disavowing magic by projecting it onto exotic non-European subjects. A good example can be seen in an advertisement made by the well-known caricature artist Peter Eng for the Viennese trade fair of 1923 entitled Die Entdeckung Wiens am Nordpol (The Discovery of Vienna at the North Pole). ${ }^{14}$ Eng's film employed a mix of animation and live-action to stage the visit of a so-called "Lapplander" to the annual trade fair held at the Viennese Prater (the city's fairgrounds). Made only a year after Robert Flaherty's successful Nanook of the North (1922), the film clearly parodies Flaherty in its pseudo-ethnographic explanations of bizarre customs at the North Pole, such as the Lapplanders' method for making "polar berry" ice cream out of polar bears. Building on such intertextual links, one can certainly place Eng's film within a broader tradition of ethnographic display. As showcases for a colo- 


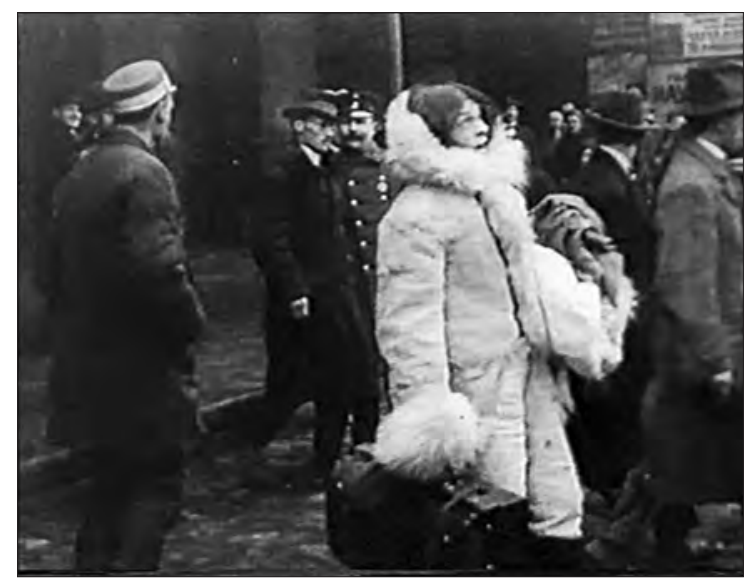

Still from

Die Entdeckung Wiens

am Nordpol

(Peter Eng, 1923)

nialist and imperialist worldview, the universal exhibitions of the $19^{\text {th }}$ century had frequently featured displays of "primitive" peoples (a practice that would later inform ethnographic film), ${ }^{15}$ and Inuit and Sami peoples had figured in ethnographic displays on the very Prater grounds featured in Eng's film. ${ }^{16}$

But while Die Entdeckung Wiens recalls the tradition of ethnographic display, it also reverses the standard divisions between European observers and indigenous exhibition; for it is now European technology that is on view, and the "Lapplander" figures as the principal spectator in the film when he visits the trade fair. To be sure, the point of this reversal was not to offer a critique of the colonial gaze, but rather to employ the fictional "Lapplander," precisely in his "primitive" capacity for astonishment, as a model for the ideal consumer. As he arrives at the fairgrounds, the exoticized figure stands out from the Europeans not only by his white furry costume set against the lean black suits, but also by his incessant gawking. His gaze turned upward and mouth agape before the spectacle of new products and technologies, the "Lapplander"-who will return to the far north with a boatload of products at the end of the film-embodies the kind of astonishment the technology fair in fact sought to generate among European visitors, most of whom would have come from the outskirts of Vienna. But the use of the "Lapplander" also allows the film to disavow this astonishment by projecting it onto the "primitive" periphery of the northern most regions of Europe. ${ }^{17}$

Such "exoticized" figures were a staple topos of advertising films in the 1920s, and Peter Eng was not the only filmmaker to use them in exhibition advertisements. The animator Hans Fischerkoesen, for example, made a similar film for Pinschewer in 1925 as an advertisement for the Frankfurter Internationale Messe. Entitled, Der Kaufmann von Bagdad, the film depicted a struggling Bagdad merchant who receives a holy sign leading him to the Frankfurt International Trade Fair, where he purchases a camel load of superior products that help his bazaar to flourish. Although Der Kaufmann von Bagdad is lost 
Poster for the Wiener Internationale Messe (Viktor Weixler and Fritz Judtmann, 1923)

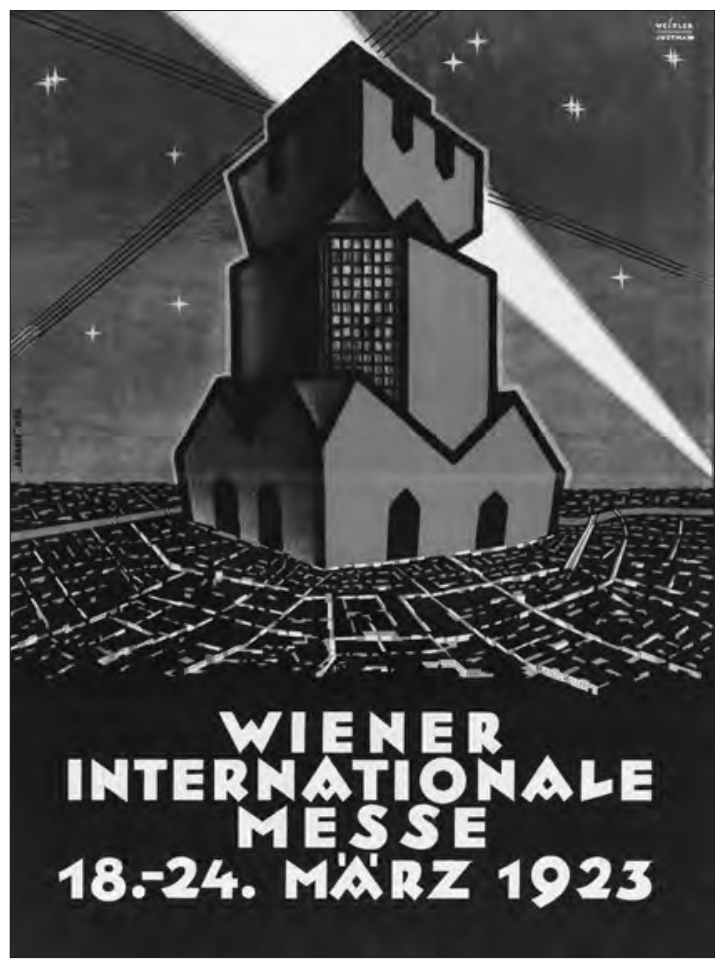

today, ${ }^{18}$ a series of surviving sketches printed in trade journals shows that the film employed a caricature aesthetic similar to that of Die Entdeckung Wiens and familiar from other advertisements of the time. Such caricature might seem to stand in contradiction to the ideal of the astounded spectator, since caricature humour, traditionally linked to political and cultural satire, has often functioned to elicit a reaction of distanced condescension on the part of audiences. This question of humour is particularly relevant in the case of colonial representations where laughter is always bound up, as Claudia Walkensteiner-Preschl observes in her own discussion of Eng's film, with "relations of power and mastery."19 But as Michael Taussig long ago argued, the sense of mastery produced by colonial laughter is always tenuous, since it can also betray, in its very defensive posturing, a flash of mimetic recognition. Thus Taussig famously argued that Western observers' delight upon finding representations of European technologies in the mola embroideries of Kuna women, even while reinforcing a sense of "colonialist mastery," also "registers a tremor in cultural identity" and a flash of mimetic recognition. ${ }^{20}$ Adapting Taussig's observations to these early exhibition advertisements, one could say that in films such as Die Entdeckung Wiens the audience's delight in the Lapplander's naive astonishment, our fascination with his fascination, also registers a latent recognition of our own propensity towards magical belief. This was a recognition also at work in films such as Nanook and it was 


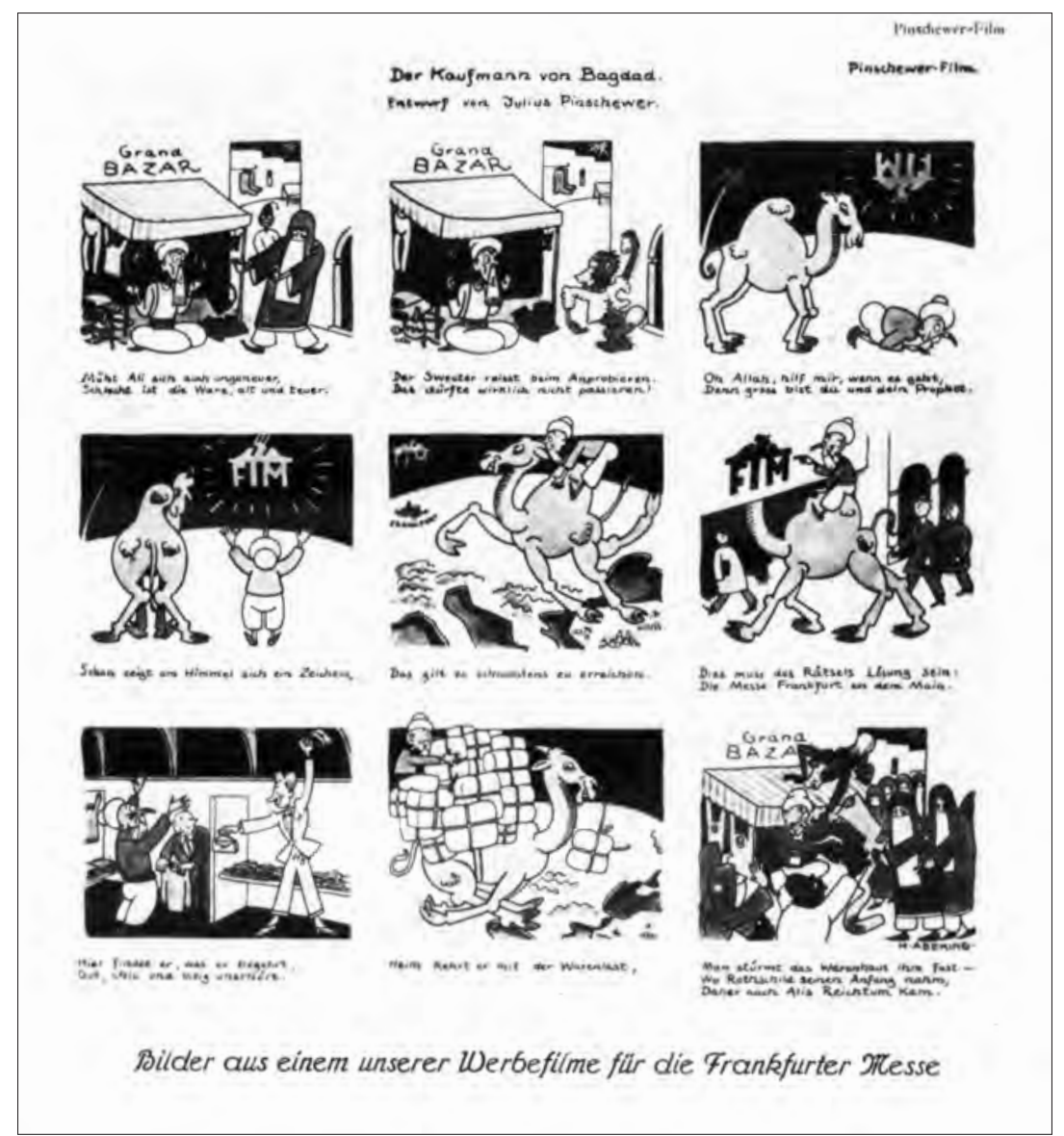

Sketches for Der Kaufmann von Bagdad (Julius Pinschewer, 1925)

everywhere operative in filmic advertising of the 10s and 20s, where figures of the "primitive" served as disavowed representations of consumers' own propensity towards astonishment.

In this management of astonishment, these films clearly look back to the kinds of marketing that occurred within and around displays of technology in exhibitions since the $19^{\text {th }}$ century, where the negotiations of fascination and familiarity often overlapped with colonial representations of "primitive" peoples. ${ }^{21}$ But one can also point to a new moment at work here. Both Die Entdeckung Wiens am Nordpol and Der Kaufmann von Bagdad were also fundamentally concerned with staging forms of spectatorship in movement. In both films, moreover, it is the exhibition trademark that serves as the catalyst that sets bodies into motion. In the Vienna film, the trademark WIM (Wiener Internationale Messe) first appears as an animated title in a "polar cinema" where the Lapplander community is shown images of the Viennese trade fair. This same trademark is 


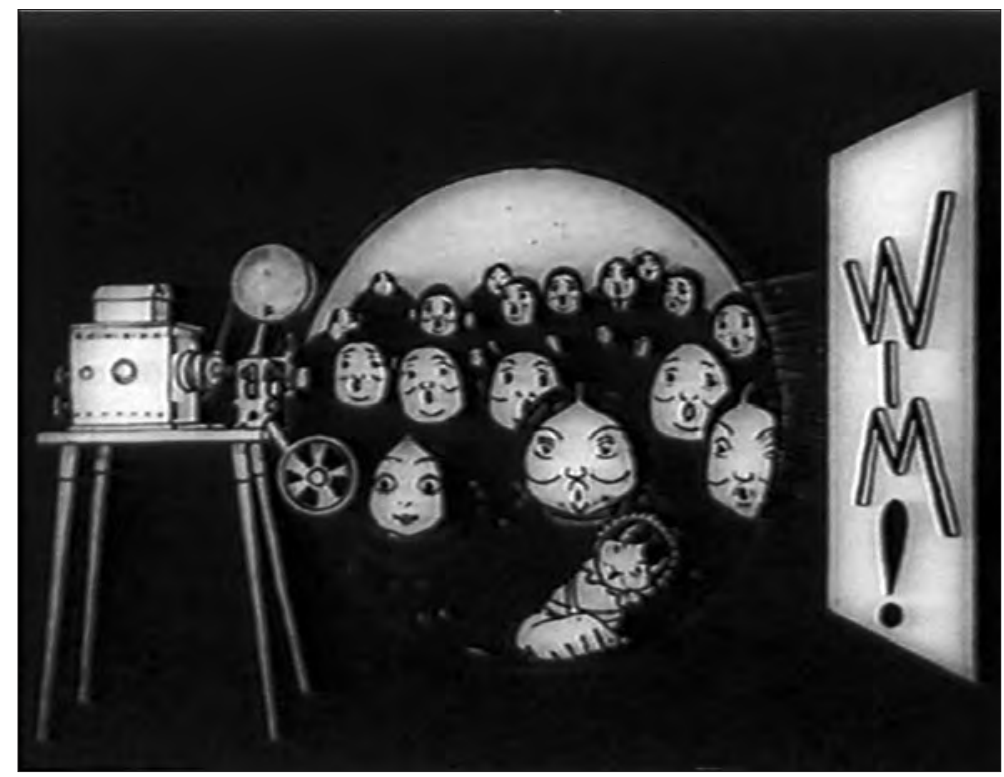

Still from Die Entdeckung Wiens am Nordpol (Peter Eng, 1923)

then transformed into a starry constellation that literally guides the main figure on his voyage to the Prater. A similar scenario unfolds in the Bagdad film, where the merchant's prayers are answered by the appearance of the trademark FIM in the night sky, which leads the merchant to the Frankfurt fair like a star of Bethlehem. These animated trademarks thus not only moved with the motion of the new filmic medium, they also served as allegories for the power these advertisements sought to claim for film: a "mimetic" power of a different order, by which moving images could set bodies into motion, propelling them into acts of consumption.

Turning to the emerging field of advertising psychology in the 1920s, one finds that advertisers indeed saw their task as one of intervening in processes of circulation. As the advertising theorist Theodor König explained in one of the first books on the subject from 1922, advertisers in the new Republic now assumed a context of mobile consumers, in which advertisements could only hope to attract what König aptly dubbed "the fleeting glance of passers-by" rather than the kinds of absorbed study characteristic of the book or the museum. ${ }^{22}$ Advertising theorists proposed all sorts of means for competing within this new marketplace of mobile and fleeting attention, above all by simplifying advertising design for rapid legibility and tailoring advertisements to attract consumer attention. ${ }^{23}$ It was precisely this competition for the fleeting attention of mobile spectators, in addition to the need for humour, which justified the widespread use of caricature. As the caricaturist Lutz Michaelis put it in an article on animation from the journal Die Reklame, caricature drawing could "concentrate, through the use of minimal lines, the most striking aspects of the things it shows, 


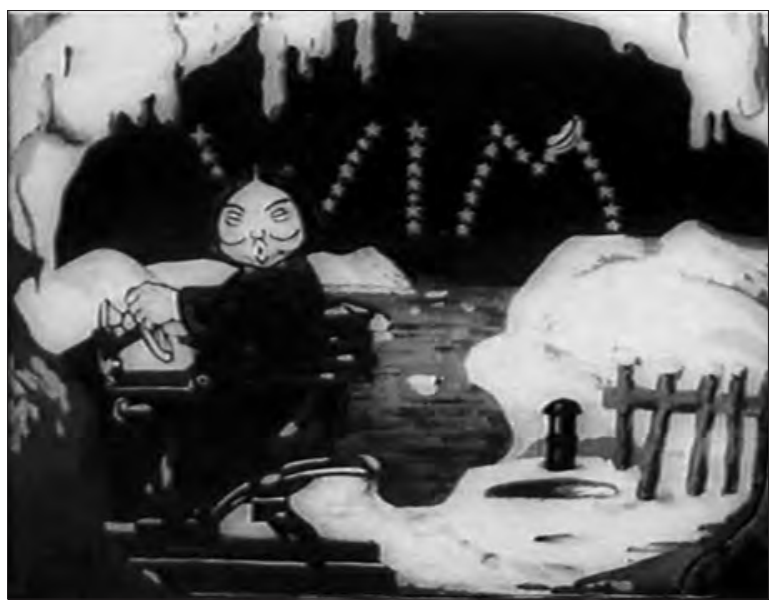

Still from

Die Entdeckung Wiens am Nordpol

(Peter Eng, 1923)

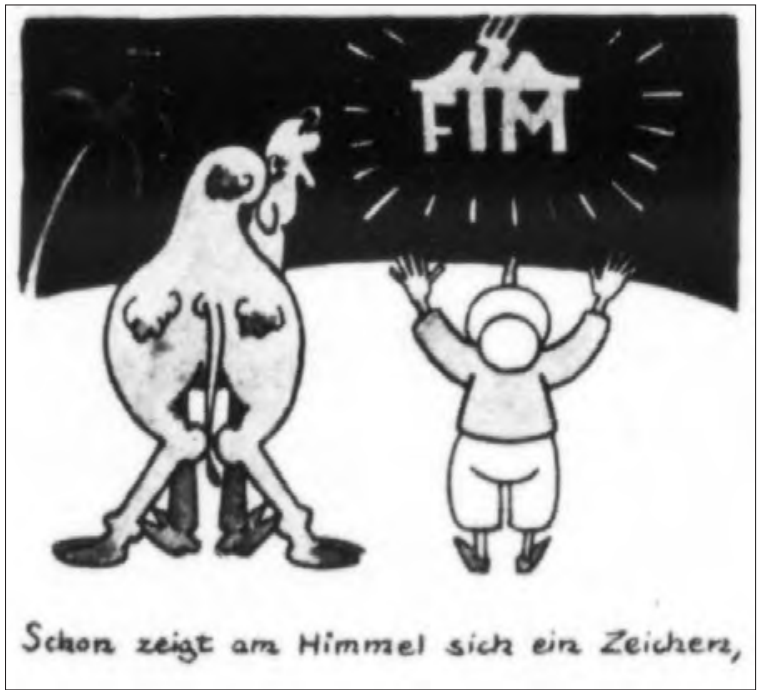

Detail from sketches for Der Kaufmann von Bagdad (Julius Pinschewer, 1925)

which should be immediately associated with the product advertised." 24

It was within the same context that advertising psychologists first became attracted to the medium of film, which presented a unique set of opportunities and challenges. On the one hand, the cinema potentially offered an ideal solution to the problem of fleeting glances on account of its ability to monopolize consumer attention, temporarily immobilized in the darkened space of the theatre. As one writer for Die Reklame describe it (in a formulation repeated endlessly in the literature of the time): "If there is any way to force consumers to attend to advertisements, then it is through film. Just think of the darkened theatre and ask yourself if there is any way to escape the effects of the image." 25 This topos of the absorbed spectator, forced to succumb to the power of the advertising image, 
Advertisement for Industriefilm portable projectors (1920)

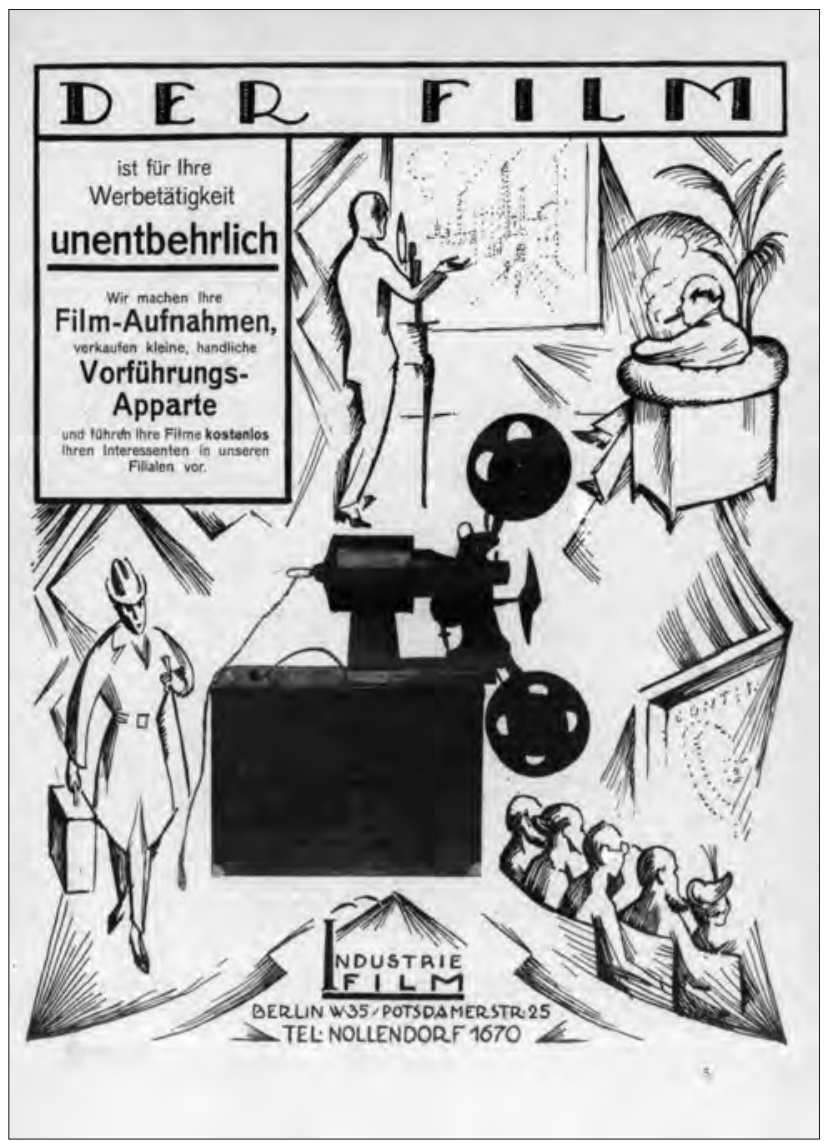

finds a representation in Peter Eng's image of the "polar cinema," where spectators appear mesmerized by the Vienna trademark. In reality, however, even producers of filmic advertisements were all too aware of the need to compete for fleeting gazes in movement. Accordingly, this period also oversaw the emergence of numerous new portable projection devices such as the "suitcase" projectors of traveling salesmen (also known as the Musterkoffer on account of their use for demonstrating sample products through film), various advertising vehicles andmost significantly for my purposes here-the so-called Filmschrank (film cabinet), which used rear projection to show advertising films on a continuous loop in shop windows and trade fairs. ${ }^{26}$

All of these projection systems were put to the test at trade fairs. While the great universal exhibitions had showcased motion pictures themselves as a technological attraction (for example in the giant Lumière projections at the 1900 Paris World's Fair), the trade fairs of the 1920s were more interested in the possibilities of mobile cinema and its use for trade and advertising. ${ }^{27}$ As early as April 1920 in the Leipzig trade fair, the Petra advertising company unveiled their 


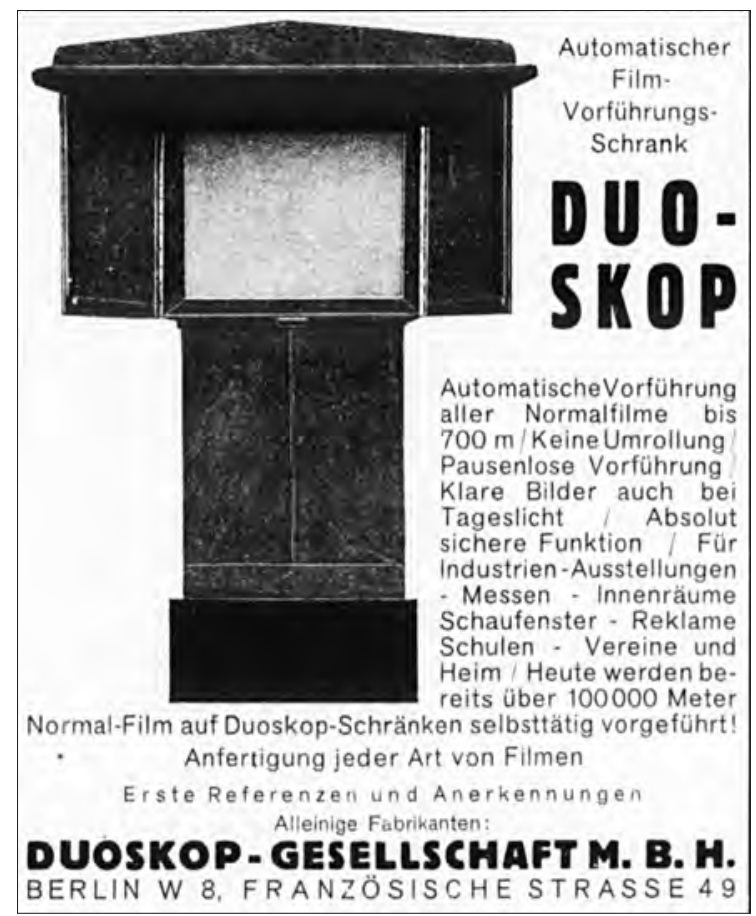

Advertisement for Duoskop "Automatic Film Projection Cabinet" (1928)

"Kinomobil," a "cinema on wheels [fahrbares Kino] equipped with a daylight screen." ${ }^{28}$ A report from the same fair in the fall of 1920 describes, alongside suitcase cinemas, the presence of a novel Tageslichtwand-Reklameschrank (daylight screen advertising cabinet) for the showing of advertising films on a continuous loop, ${ }^{29}$ and a similar apparatus by the company Kinota generated much attention in the Frankfurter Internationale Messe the same year. ${ }^{30}$ Such film cabinets would go on to become a frequent presence in exhibitions by the second half of the decade, and Pinschewer himself-who boasted of his prominent visibility in exhibitions-used them widely. ${ }^{31}$

If such mobile technologies show up within the context of exhibitions, this is surely not by chance. Trade fairs were spaces for showcasing new technologies, but they also represented an ideal forum for trying out new ideas about consumer circulation and reception. In this sense, as Haidee Wasson has argued in her own analysis of small screens at the 1939 New York World's Fair, the preoccupation with new film technologies at such fairs points beyond the immediate technologies in question to broader cultural shifts that would soon become dominant in the postwar era: "The fair...can be understood as a predictive and telling inventory for a paradigmatic shift in film culture, inserting the cinema into an important history of mobility and small-scale moving image display that served an increasingly integral everyday role throughout the interwar period and beyond." 32 Above all, the newly professionalized trade fairs of the 1920s served as laboratories for 
Advertisement for Pinschewer advertising films shown on film cabinets (1927)

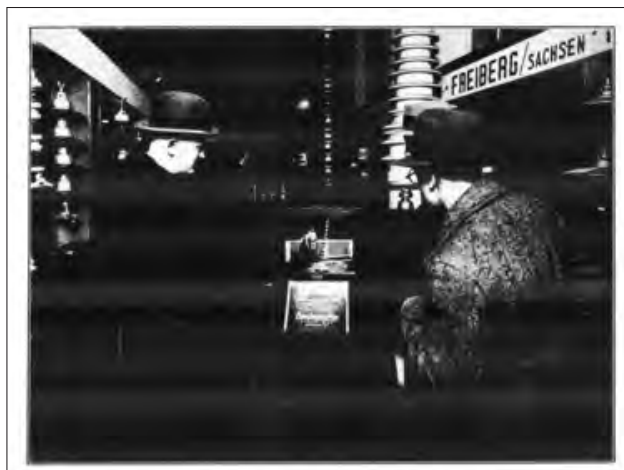

Der Film im Austellungs- und Verkaufsraumein neuer Weg des

\section{Pinschewer $\sim$ Films}

\section{Auskunlt:}

Werbefilm G.m.b.H. sowie Industriefilm A.-G. Berlin W 35 . Genthiner Strafie 32 Gemeinsame Leitung: Julius Pinschewer

testing new modalities of social management in the commercialized public spheres of postwar democratic society. With its competing displays arranged in a clearly demarcated ambulatory space, the exhibition space appeared as a useful arena for observing the newly mobilized attention of consumers and testing the relations between advertising images and audiences in circulation. Indeed, commentaries on exhibitions in the trade literature of the time attest to the fact that the products and technologies on display were, in fact, only half the spectacle: just as interesting, for advertising experts, was the observation of the crowds, their movements and above all their budgeting of attention. Thus the same journalist who described the Kinomobil at the 1920 Leipzig fair went on to describe the "genuine traffic jams" [wahrhafte Stauungen des Verkehrs] caused by the model display window for the Leipzig underwear company Strumpf-Eulitz. ${ }^{33}$ Another journalist, reporting from the Frankfurt International Trade Fair in 1920 for the journal Seidels Reklame, approvingly described the placement of the newly patented "Atrax" system for projecting slide advertisements in the entrance hall to the exhibition, where "every visitor to the fair had to walk through this space...on the floor of which the colourful 'Atrax' images appeared as if by magic." 34

Little wonder, then, that discussions of film technologies in exhibitions would emphasize their relations with an ambulatory public. One report stipulated that the new film cabinets were "designed to be set up at traffic points 


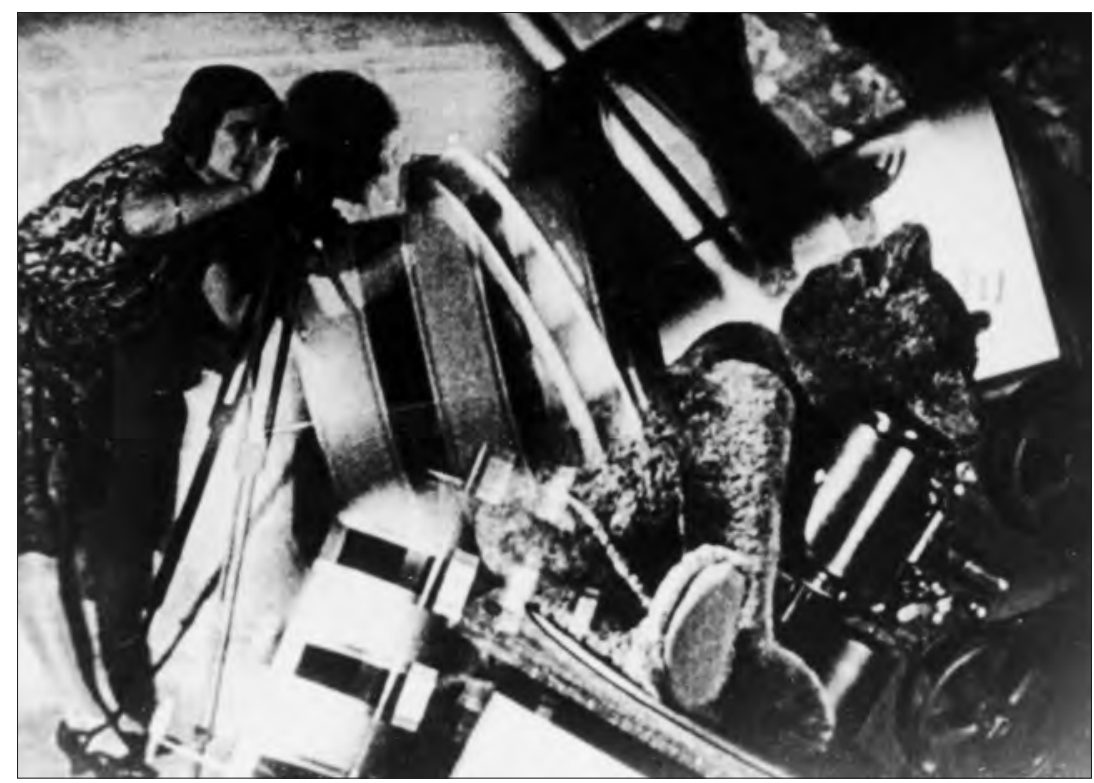

Still from Kipho (Guido Seeber, 1925)

[Verkehrspunkten],"35 and another writer suggested that advertising films should be projected "at nodal points of exhibition traffic" (an Brennpunkten des Messeverkehrs). ${ }^{36}$ It is against the background of this concern with spectatorial traffic (Verkehr) that we should understand the representations of moving bodies in film exhibition advertisements such as Die Entdeckung Wiens am Nordpol and Der Kaufmann von Bagdad. As advertisements for trade exhibitions, these films sought above all to showcase the power of film (represented in the films by the all-important trademarks) to steer the bodies of circulating consumers toward productive ends.

The claim to channel movement through filmic images took a different, more "elementary" form in the newest form of advertising film in the 1920s, that of abstract film. It is well known that nearly all of the proponents of avant-garde film in Germany participated widely in advertising, and the advertising industry also showed a remarkable interest in the possibilities of abstract film. Always the pioneer, Pinschewer hired Ruttmann and Lotte Reiniger to make advertising films for tires, liqueur, perfume, and chocolate as early as 1921, and there would follow many examples such as Oskar Fischinger's Kreise (1933) for the Tolirag advertising agency and Wolfgang Kaskeline's Zwei Farben for Muratti cigarettes. There were many reasons for this synergy, but the most important one resided in a common interest among filmmakers and advertisers in the potential of visual motion-particularly when ordered rhythmically - to open up new modalities of "mimetic" experience, where the movements on screen might elicit corresponding "movements" within the psychophysical apparatus of spectators. The most influ- 
ential articulation of this argument came from the advertising theorist Fritz Pauli, whose 1926 study Rhythmus und Resonanz als ökonomisches Prinzip in der Reklame (Rhythm and Resonance as Economical Principles in Advertising) proposed the rhythmical organization of advertisements in posters, electric light installations, and film. Drawing on recent discussions of rhythm from biology, science, and engineering, Pauli argued that visual rhythms could be harnessed in advertising to exert what he called a Resonanzzwang (compulsory resonance), by which sensory motor activity of consumers could be controlled and standardized no less precisely than those of a Fordist factory. ${ }^{37}$

To be sure, Pauli's model of rhythmical advertising, although receiving widespread acclaim among advertising circles upon its appearance, was not the only one around, and much advertising psychology of the period relied on a more familiar model of forging psychological associations in order to motivate subsequent acts of consumption. ${ }^{38}$ Pauli's interest in the power of rhythm did however clearly resonate with the work of experimental filmmakers. As I have argued elsewhere, ${ }^{39}$ it helps us to understand the project behind one of the best-known exhibition advertisements of the mid-1920s, Guido Seeber's promotional film for the 1925 Kipho exhibition of the German film and photography industries. Employing techniques of in-camera montage, Seeber's film presents the film industry as a precisely calibrated apparatus of Fordist movement in the form of circular cranks, gears, lights, and film platters. But the film also represents this system as one capable of integrating moving bodies -both the moving bodies shown on the screen and the body of consumers-into its rhythms. Kipho ends, famously, with a citation of the sequence from Robert Wiene's The Cabinet of Dr. Caligari (1920) in which the words " $D u$ mußt Caligari werde" write themselves across the nighttime sky before the psychiatrist's astounded gaze. Only now, in a move reminiscent of the animated trademarks from Die Entdeckung Wiens and Der

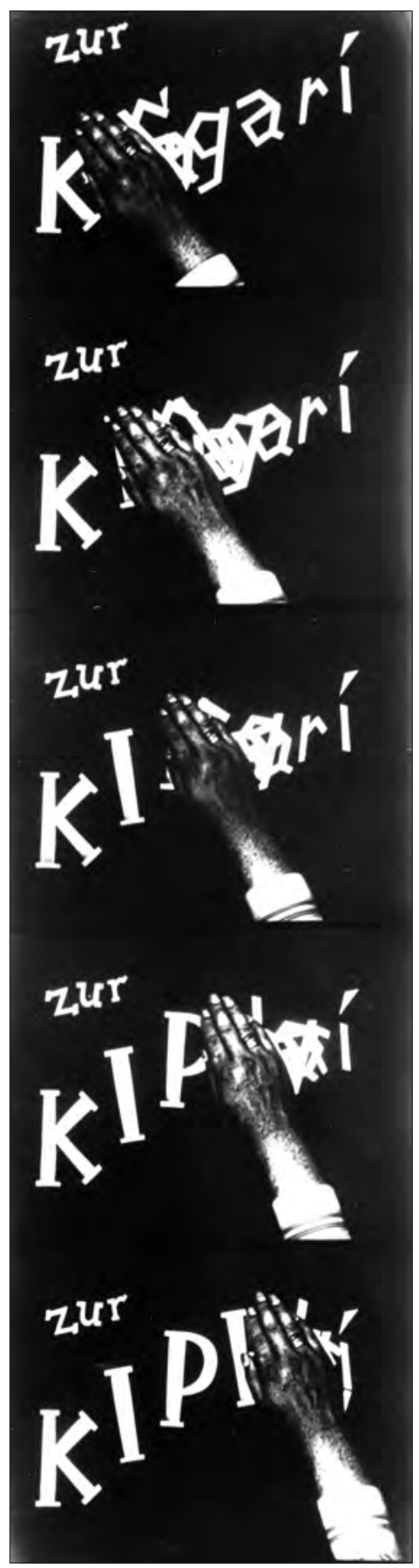

Stills from Kipho

(Guido Seeber, 1925) 


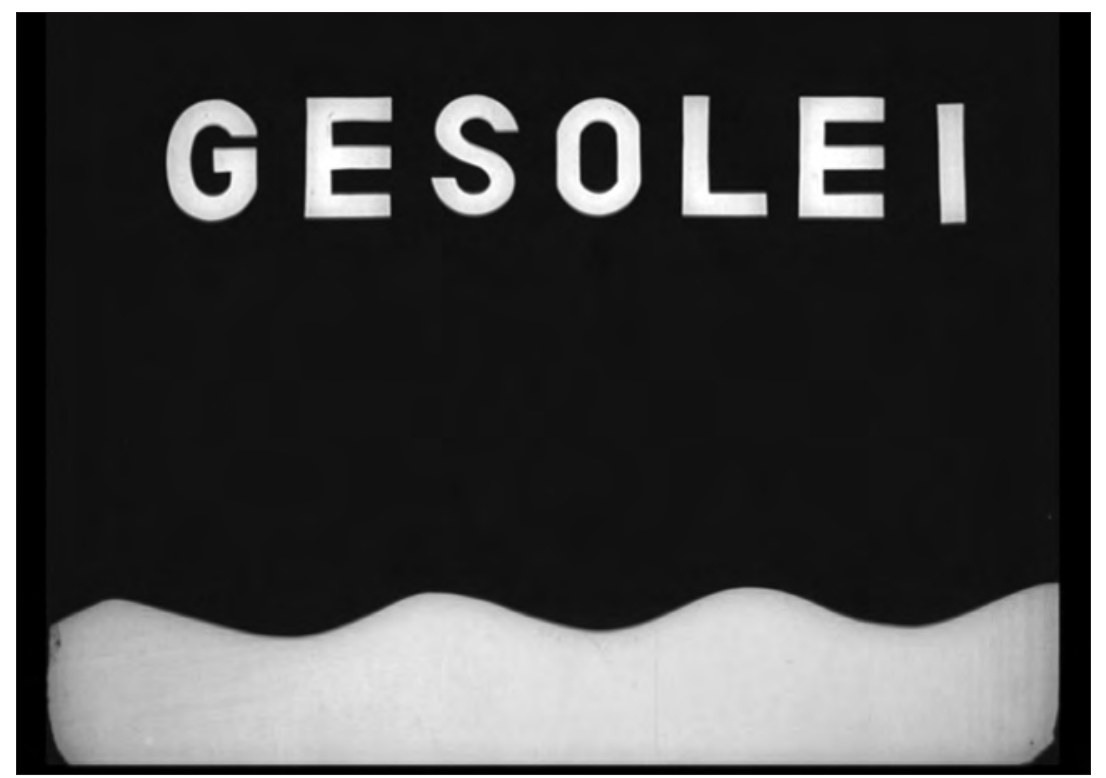

Still from Der Aufstieg (Walter Ruttmann, 1926)

Kaufmann von Bagdad, the Caligari sentence is transformed into the injunction: Du mußt zur Kipho! literally commanding audiences to go to the exhibition. Like Die Entdeckung Wiens, Kipho thus claims a mimetic power for moving images, now organized rhythmically, to move spectators into action.

The year after the Kipho exhibition, Ruttmann himself made another exhibition advertisement, Der Aufstieg (The Ascent), for the Gesolei exhibition of Health, Social Welfare and Body Culture in Düsseldorf. ${ }^{40}$ While conceived as an educational endeavour in the tradition of the Dresden Hygiene exhibition of 1911, the new exhibition - the largest and costliest of the Weimar Republic-in fact had a much broader mission: namely to promote a sense of "regenerating" the national body (and specifically to symbolically reintegrate the Rhineland) after the "humiliations" of war and a prolonged occupation by French forces. To this end, the organizers undertook a massive building project, overseen by the architect Wilhelm Kreis and involving well-known artists such as Peter Behrens, in which 40,000 square metres of terrain around the Düsseldorf Kunstpalast were redesigned to house 174 buildings including numerous pavilions and exhibition spaces, a planetarium, a nursery, bathhouses, courtyards, gardens and restaurants.

Many of these buildings were designed to last and clearly formed part of a symbolic reclaiming of the Rhineland. But as much as the Gesolei was about monumental buildings, it was also all about the experience of movement; a good portion of the exhibitions grounds was dedicated to kinetic attractions familiar from amusement parks, such as the miniature train that ran the circumference of the exhibition site, a set of bumper-cars and a large wave pool dubbed the Planschetarium in analogy to the exhibition's planetarium. ${ }^{41}$ Such attractions 


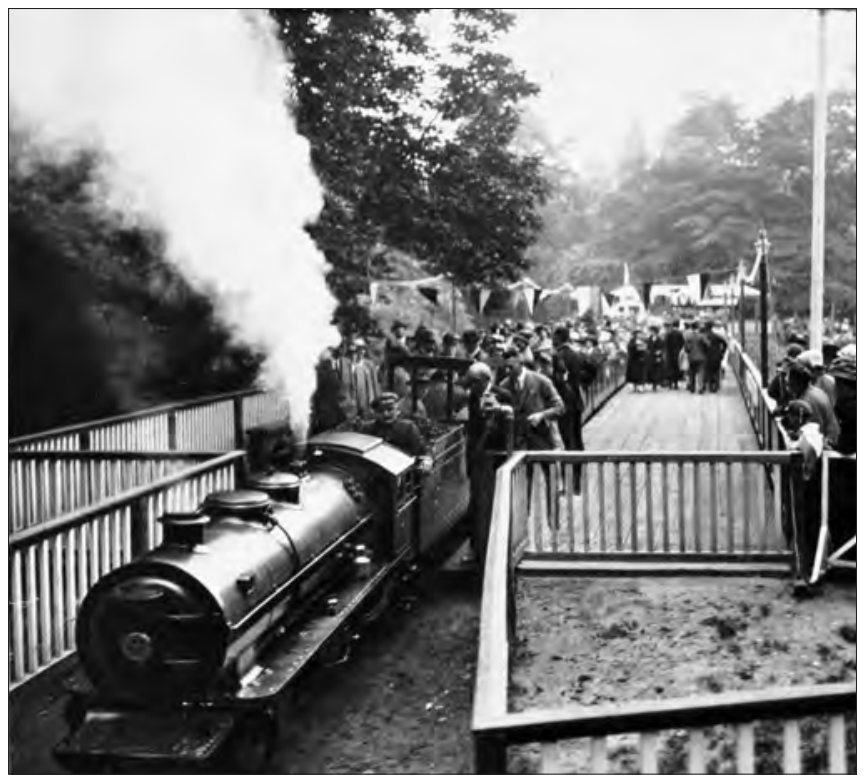

Lilliput Train at the Gesolei exhibition (1926)

formed a part of the more widespread interest in amusement parks as spaces for assimilating new experiences of movement in the industrial age. ${ }^{42}$ Moreover, as Kreis described it in an article printed in Die Reklame, one of his main concerns in designing the exhibition grounds was precisely the regulation of pedestrian traffic (what he called umlaufender Verkehr) as spectators moved through the various sections of the exhibition devoted to public hygiene, social welfare, physical exercise, working conditions, medicine, and eugenics. ${ }^{43}$ Kreis himself was largely influenced by the school around the architectural theorist Wilhelm Schmarsow, which drew on the psychology of empathy to conceptualize architecture as a time-based rhythmical art: a phenomenon analogous to bodily processes such as heartbeats and breathing experienced in a more or less harmonious fashion by bodies in movement. ${ }^{44}$ According to art historians Gabriele Genge and Jürgen Wiener, this was precisely the notion that Kreis brought to bear on his designs for the Gesolei exhibition, which sought - through the reduction of ornamentation and the emphasis on alternation, repetition, and interrelationship - to induce a sense of rhythmical regularity in visitors. ${ }^{45}$ As Kreis himself described it, "visitors will experience a sense of regeneration [Erholung] when they find the same nerve-calming composure at work in all of the halls and pavilions, which do not attempt to confuse or surprise the mind but rather lead it towards the pleasure of study." 46

Rhythm was also a central topic within the exhibition itself, which demonstrated, among other things, the link between bodily health and vital rhythmsfor example in displays of correct blood circulation, variations on rhythmical exercise, or an entire room devoted to breathing. ${ }^{47}$ And this same association of 


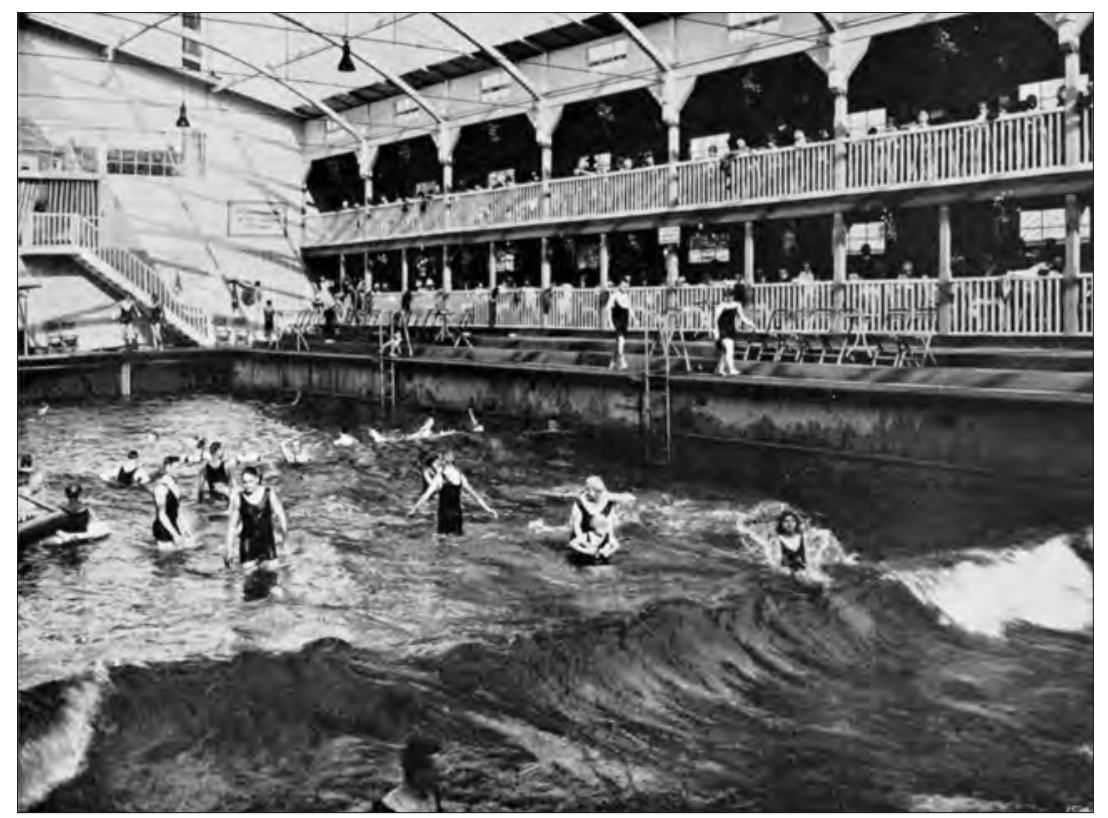

"Planschetarium" wave pool at the Gesolei exhibition (1926)

rhythmical movement and vitality can be seen in Ruttmann's advertising film, which sought to depict the process by which the German nation would "climb" back up to health after the ravages of war, occupation, and inflation. Focusing on the figure of the "German Michel" (an "everyman" figure personifying the German nation familiar from WWI propaganda), the film shows him sickly and frightened amidst exploding shells and clashing bayonets before ultimately being restored to health by bodily exercise. Undergirding this proto-narrative dimension, however, is also a recognizable trajectory in the patterns of movement, which display obvious affinities to the sickness and health of the national body. Whereas the earlier sequences of the film are dominated by chaotic and conflicting movement patterns - the clashing of swords, frenetic explosions, stormy waves, and a snake writhing in violent spasms - the latter part of the film is dominated by visions of regular rhythmical flow. As his vitality returns, the Michael figure, whose eyes now appear to flash red to the rhythm of his vital pulse, can be seen pumping weights rhythmically or turning flips in synch with the rhythmical motion of the waves below. If these waves in Ruttman evoke the symbolic space of the Rhine where the Gesolei took place, they also suggest the waves of the Planschetarium, an attraction copied from the Dresden Hygiene exhibition designed to let visitors experience the beneficial effects of rhythmical wave movement on their own bodies. ${ }^{48}$ Ruttmann's film, that is, visualized the very experience of resonance that exhibition designers sought to elicit in visitors, a resonating power that was also attributed to moving images generally, and particularly to the rhythmical images of abstract film. 


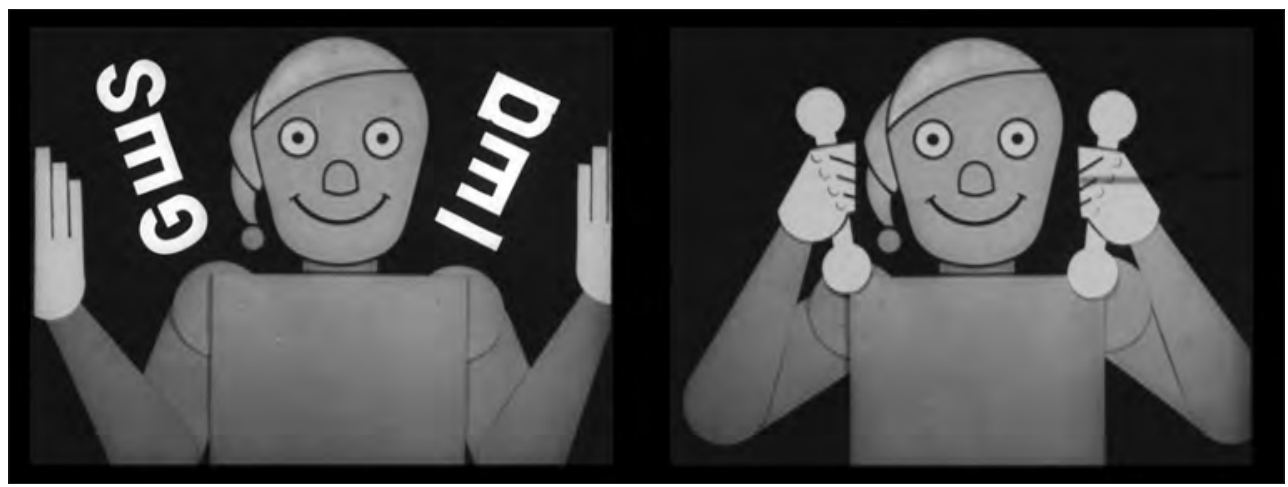

Still from Walter Ruttmann, Der Aufstieg (1926)

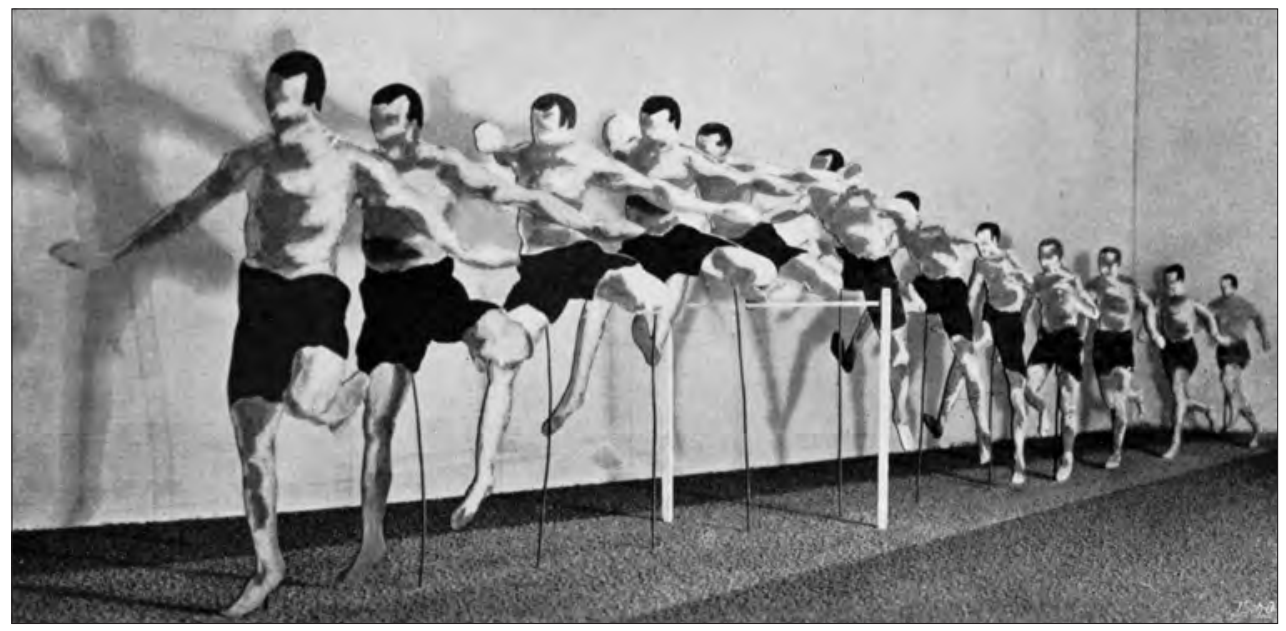

Representation of athletic movement at the Gesolei exhibition (1926)

Once again, it is the trademark that serves as the catalyst of this experience. Halfway through the film we see the animated letters Gesolei emerge from a bell (a frequent motif of exhibition advertising) and proceed to order the chaotic waves at the bottom of the screen into a regular rhythmical flow, stamp out the writhing snake attacking the Michel figure, and finally transform into the dumbbells with which he will practice his rhythmical gymnastics. At the end of the film, the same trademark becomes, as in Seeber's Kipho film, a direct injunction, commanding Ruttmann's spectators to proceed "up into the Gesolei!" [auf in die Gesolei!]." As in other exhibition advertisements, the animated trademark, here hovering between word and image, is imagined as being endowed with a "mimetic" force, which can literally propel spectators into action.

Images of bodies in movement played no small role in the Gesolei exhibition itself. Among the hundreds of slides, paintings, graphs, charts, dioramas, scien- 


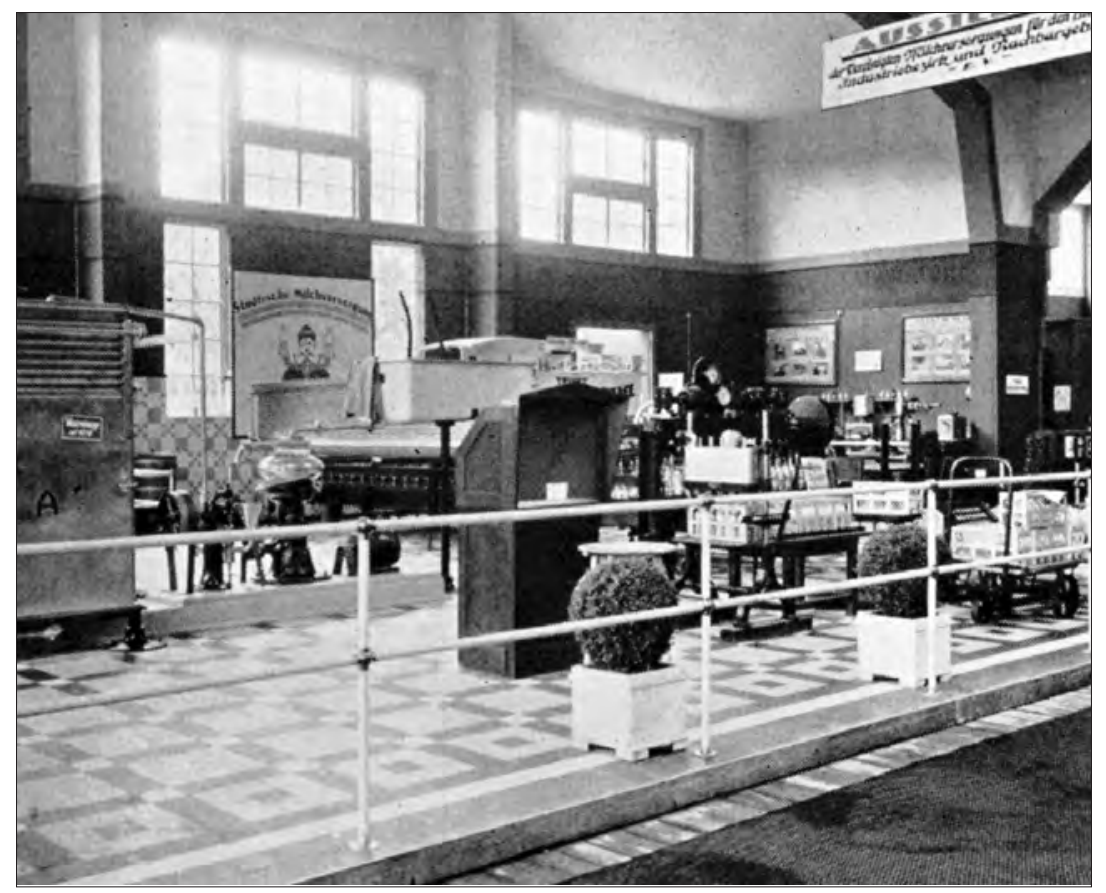

Duoskop film cabinet used at the Gesolei exhibition (1926)

tific models, and other forms of visual illustration, there was, as Angela Stercken has pointed out, a widespread concern with visualizing normative forms of efficient movement, both in work and leisure. ${ }^{49}$ To be sure, the exhibition directors explicitly chose not to include traditional film projections among the exhibition's visual spectacles. But as the scientific director, Marta Fraenkel, explained in an exhibition catalogue, this was not on account of any inherent prejudices against film as a visual medium, but rather (and significantly for my discussion here) on account of the organizers' desire to keep audiences moving: "The exhibition directors emphasized again and again that the psychology of an exhibition visitor is that of a walker [Wanderer] and not that of a movie theater audience." 50 Moreover, it was precisely on account of this appeal to an audience in motion that organizers did include, in several exhibition halls and pavilions, portable film cabinets provided by the company Duoskop to show ten-minute films in loops. In Fraenkel's words: "The exhibition directors, following current trends, arranged for the presence of daylight film [Tageslichtfilm]."

Just as interestingly, the exhibition also included a much-discussed demonstration of abstract visual movement in the central planetarium, where the experimental composer Alexander László demonstrated his "colour-light-music," in which abstract coloured light projections and slides were triggered via a specially prepared piano. ${ }^{52}$ Reminiscent of the many experiments in colour music from the 1910s, which formed the direct precursors of abstract film in the 20s, László's 


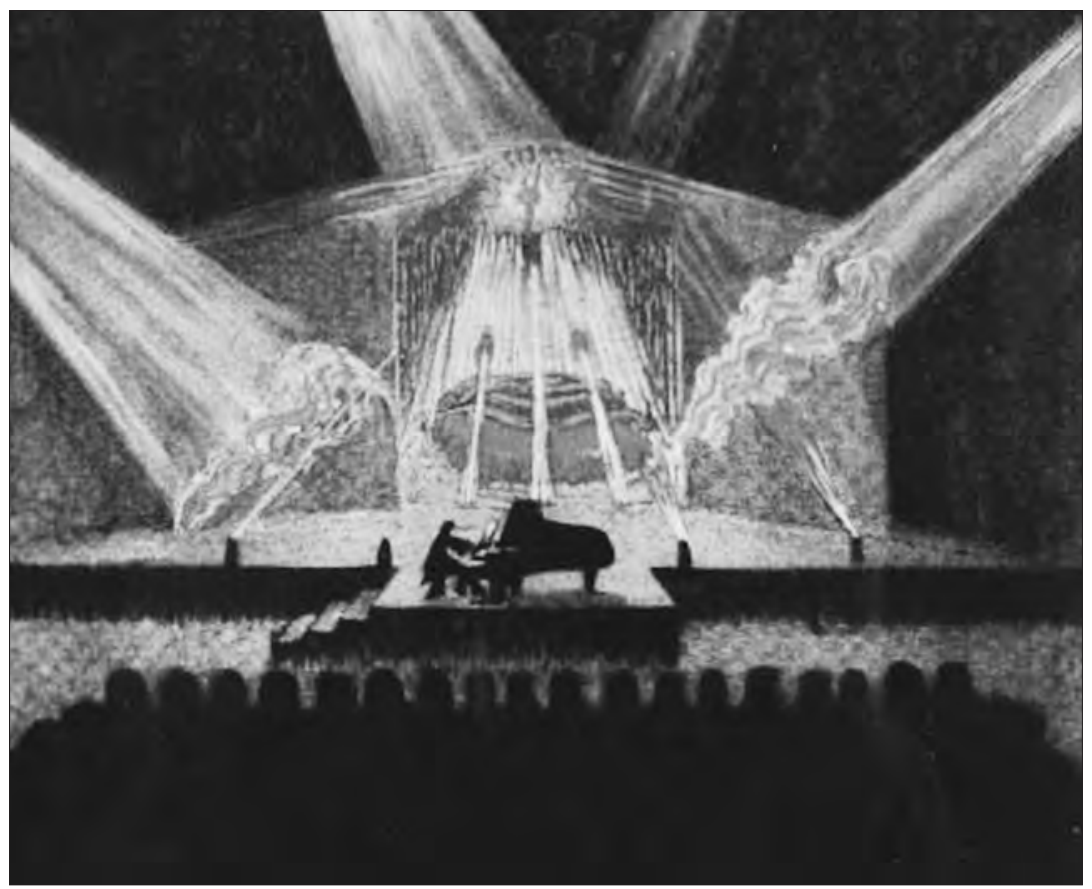

Alexander László performing color-light-music. Watercolor by Matthias Holl (1925)

installation-which in some manifestations had included films by Oskar Fischinger-transformed the planetarium dome into a spectacle of abstract kinetic movement now detached from any identifiable object. ${ }^{53}$ The Lichtfarbkugel also represented a distant echo of Loïe Fuller's fin-de-siècle electricity dances and would find another echo in one of the exhibition's other main attractions, a light show projected onto the central fountain. ${ }^{54}$

Like the other attractions at the Gesolei, Lásló's abstract light show was intended for mobile spectators, who could come and go during any of the eight performances he repeated daily. ${ }^{55}$ On one level, this new mode of spectatorship, along with the myriad interactive spectacles at these exhibitions, recalls Benjamin's well-known arguments that art in the modern age was increasingly characterized by an "exhibition" value that implied more hands-on, active forms of engagement by an audience of "experts." ${ }^{56}$ But it would be a mistake, I think, to see anything inherently progressive in these new forms of aesthetic presentation for mobile consumers. From the expanded cinema of the 1960s to Jane Gaines's concept of "political mimesis," in which the violence of injustices shown on the screen "moves viewers to want to act," most models of "activist" filmmaking have maintained an association between the overcoming of passive spectatorship and radical politics. ${ }^{57}$ But the effort to "move" audiences, along with the desire to regulate those movements, has informed various experiments with alternative film spectatorship throughout the $20^{\text {th }}$ century. This is particularly 


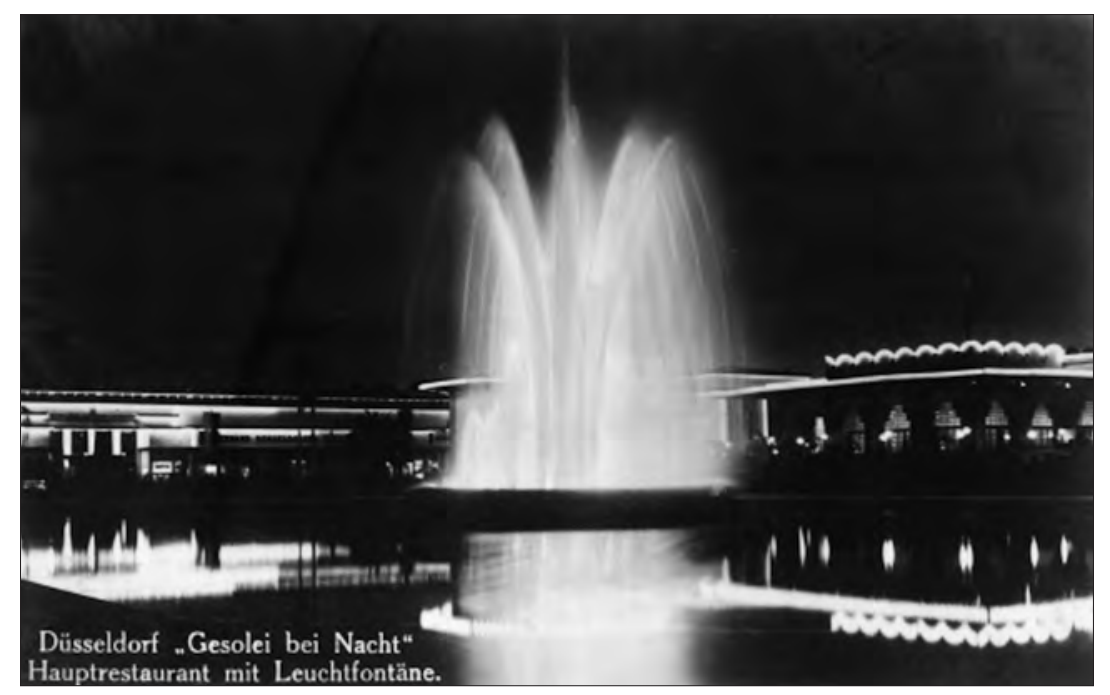

Central "light fountain" (Leuchtfontäne) at the Gesolei exhibition (1926)

true of the realm of advertising, which assumed a mobile audience and sought to use moving images to channel audience activity into acts of consumption. If filmic advertising and the exhibition shared anything in the 1920s, it was, above all, their status as "laboratories" for testing new methods of eliciting and channelling such spectatorial movement within an emerging consumer society.

Such explorations in mobile consumer attention form an obvious contrast to our own culture of film and video installations, where filmmakers have once again looked to the museum as a space to remove filmic images from circulation and re-examine their history..$^{58}$ In distinction to such critical or archival practices, which could once again be likened to surrealist appropriations of outworn commodities for non-utilitarian purposes, experimental filmmakers of the 1920s looked to the trade exhibition as a space in which to contribute to capitalism's commercial culture, elaborating techniques of spectatorship for the future rather than revisiting the past. While these techniques clearly drew on the management of wonder and astonishment elaborated in $19^{\text {th }}$-century universal exhibition, along with its characteristic colonial tropes of primitivism, they increasingly focused on movement as the key category of consumer spectatorship within the mass democracies and public spheres that emerged after WWI. Whatever else they might have been displaying, the newly professionalized trade exhibitions of the 1920s offered key sites for observing the new spectator in motion. 


\section{NOTES}

1. Dominique Païni, Le temps exposé: Le cinéma de la salle au musée (Paris: Cahiers du cinéma, 2002), 68. Approaching this phenomenon from the other end, many museum historians have argued that the literal and figurative incorporation of film into museums in recent decades has "opened the way"-as François Penz writes in a recent volume-"for new forms of museum spectatorship, making our cultural heritage more interesting and engaging." François Penz, "Museums as Laboratories of Change: The Case for the Moving Image," in Film, Art, New Media: Museum without Walls?, ed. Angela dalle Vacche (New York: Palgrave, 2012), 279. Going a step further, Mieke Bal finds the influence of film in other (non-filmic) museum exhibitions in recent decades, which incorporate a filmic grammar (close-ups, long shots, pans, etc.) into their layout and seek to render the exhibition space more dynamic by foregrounding the cinema's principal mode of "movement in vision." Mieke Bal, "Exhibition Practices," PMLA 125.1 (January 2010): 20.

2. Jean Michel-Frodon, for example, in his introduction to an issue of Cahiers du Cinéma devoted to the cinema in the museum (2006), declared the decision to devote the entire Centre Pompidou to Godard's Travels in Utopia exhibition on film history to "a happening [événement], with the novel and decisive character that this word presupposes" and argued that Godard's exhibition was indicative of a genuine "turning-point" (tournant) in film history. Jean-Michel Frodon, "Le grand tournant," Cahiers du cinéma 611 (2006): 8-9. All translations are mine unless otherwise stated.

3. Exemplary here is Haidee Wasson's work on the development of the film library at the Museum of Modern Art, which helped to transform the image of the museum away from that of a "mausoleum" housing inert cultural artifacts and toward a "living museum," whose forms of reception and networks of distribution could find a "model" in the film industry. Haidee Wasson, Museum Movies: The Museum of Modern Art and the Birth of Art Cinema (Berkeley: University of California Press, 2005), 73. See also Wasson, "Big, Fast Museums / Small, Slow Movies: Film, Scale and the Art Museum," in Useful Cinema, ed. Charles Acland and Haidee Wasson (Durham: Duke University Press, 2011), 178-205, esp. 185.

4. Tom Gunning, "The World as Object Lesson: Cinema Audiences, Visual Culture and the Saint Louis World's Fair," Film History 6.4 (1994): 422-444; Gunning, "Re-Newing Old Technologies: Astonishment, Second Nature, and the Uncanny in Technology from the Previous Turn of the Century," in Rethinking Media Change: The Aesthetics of Transition, ed. David Thorburn and Henry Jenkins (Cambridge and London: MIT Press, 2003), 39-59.

5. On the avant-garde and the museum, see especially Andreas Huyssen, Twilight Memories (London: Routledge, 1995), 13-37, esp. 17-19. Among avant-garde groups, it was above all those with ties to Constructivism and the Bauhaus who eagerly collaborated with exhibitions. Other groups, such as the Surrealists, were less keen on legitimating capitalist institutions. The Surrealists launched a campaign against the 1931 Colonial Exhibition in Paris, staging a counter "Exposition Anticolonial." On this point, see Lynn Palermo, "L'Exposition Anticoloniale: Political or Aesthetic Protest?" French Cultural Studies 20 (2009): 27-46.

6. See Olivier Lugon, "Dynamic Paths of Thought: Exhibition Design, Photography and Circulation in the Work of Herbert Bayer," Cinema Beyond Film: Media Epistemology in the Modern Era, ed. François Albera and Maria Tortajada (Amsterdam: Amsterdam University Press, 2010), 117-145. Wasson, "Big, Fast Museums / Small, Slow Movies," 185. On El Lissitzky's exhibition designs, see Ulrich Pohlmann, "El Lissitzky's Exhibition Designs: The Influence of his Work in Germany, Italy and the United States 1923-1943," in El Lissitzky: Beyond the Abstract Cabinet: Photography, Design, Collaboration, ed. Margarita Tupitsyn (New Haven: Yale University Press, 1999), 52-65.

7. On Seeber and the Kipho, see Michael Cowan, Technology's Pulse: Essays on Rhythm in German Modernism (London: IGRS-University of London, 2012), 141157. On Richter's film, see Andres Janser and Arthur Rüegg, Hans Richter: New 
Living: Architecture, Film, Space (Baden: Lars Müller Publishers, 2001); Thomas Elsaesser, "Die Stadt von morgen. Filme zum Bauen und Wohnen," in Geschichte des dokumentarischen Films in Deutschland, Band 2: Weimarer Republik 19181933, ed. Klaus Kreimeier, Antje Ehmann and Jeanpaul Goergen (Stuttgart: Reclam, 2005), 381-409.

8. By the end of the 1920 s, there were over 80 companies producing advertising films in Germany alone. See Ingrid Westbrock, Der Werbefilm: Ein Beitrag zur Entwicklungsgeschichte des Genres vom Stummfilm zum frühen Tonfilm (Hildesheim: Georg Olms, 1983), 62. For more on the development of film advertising in relation to postwar advertising culture generally, see my article "Absolute Advertising: Walter Ruttmann and the Weimar Advertising Film," Cinema Journal 52.4 (2013), 49-73.

9. For more on this transition, see for example Harold Bathelt, "International Trade Fairs and World Cities: Temporary vs. Permanent Clusters," in International Handbook of Globalization and World Cities, ed. Bed Derudder, Michael Hoyler, Peter J. Taylor and Frank Witlox (Cheltonham: Edward Elgar, 2012), 177-188, esp. 181.

10. As one writer described it, the main goal of the Frankfurter Inaternationale Messe, the first meetings of which were held during the occupation of Frankfurt by French troops in 1919, was to "reconnect with world economic relations." Stadtrat Dr. Landmann, "Die Frankfurter Messen," Die Reklame 15 (1922): 103.

11. Gunning, "Renewing Old Technologies," 43.

12. Ibid., 47.

13. See for example J. M. Merich, "Die III: Frankfurter Internationale Messe," Seidels Reklame 5 (1920): 285. In this sense, the new trade exhibitions took over the status of world exhibitions as-in the words of Walter Benjamin-"places of pilgrimage to the commodity fetish." Walter Benjamin, The Arcades Project, trans. Howard Eiland and Kevin McLaughlin (Cambridge: Harvard University Press, 1999), 7.

14. The film was originally attributed to Ladislaus Tuszinski, but a research project led by Christian Dewald of the Filmarchiv Austria revealed that Eng made it. For more on Eng's career, see Thomas Renolder, "Animation in Österreich: 1832 bis heute," in Die Kunst des Einzelbildes: Animation in Österreich, ed. Christan Dewald, Sabine Groschup, Mara Mattuschka and Thomas Renolder (Vienna: Filmarchiv Austria, 2010), 65-66, 70-74.

15. See for example Allison Griffiths, Wondrous Difference: Cinema, Anthropology and Turn-of-the-Century Visual Culture (New York: Columbia University Press, 2002), 46-86; Gunning, "The World as Object Lesson," 433-444.

16. For the presence of "Lapplander" (Sami) in ethnographic exhibits, see for example Eric Ames, Carl Hagenbeck's Empire of Entertainments (Seattle: University of Washington Press, 2008), 18-22, 57-61. For discussions of "Lapplander" performers in the Prater, see Werner Michael Schwarz, Anthropologischer Spektakel: Zur Schaustellung 'exotischer' Menschen, Wien 1870-1910 (Vienna: Turia und Kant, 2001), 21-23.

17. As Werner Schwarz points out in his history of ethnographic exhibition in Vienna, "Lapplanders" (or Sami peoples) held a unique place in the European colonial imaginary because they were, in fact, "Europeans" and as such a figure of the "primitive" within Europe itself. See Schwarz, 21.

18. For documentation, see André Amsler, "Wer dem Werbefilm verfällt ist verloren für die Welt": das Werk von Julius Pinschewer, 1883-1961 (Zurich: Chronos, 1997), 36; Günter Ägde, Flimmernde Versprechen: Geschichte des deutschen Werbefilms im Kino seit 1897 (Berlin: Verlag des Neue Berlin, 1998), 31.

19. Claudia Walkensteiner-Preschl, "Humoristisches in den Animationsfilmen der 1920er Jahre: Ein Beitrag zur österreichischen Geschichte des Animationsfilms," in Die Kunst des Einzelbildes, 192. 
20. Michael Taussig, Mimesis and Alterity (New York: Routledge, 1993), 226.

21. On colonial representations in German advertising, see especially David Ciarlo, Advertising Empire: Race and Visual Culture in Imperial Germany (Cambridge: Harvard University Press, 1911).

22. Theodor König, Reklame-Psychologie: Gegenwärtiger Stand-ihre praktische Bedeutung, 2nd ed. (Munich: R. Oldenbourg, 1924), 47.

23. As one writer for the journal Das Plakat described it in 1920, "It has become commonplace to demand of the advertising poster that it be identifiable and comprehensible in a single glance for people driving by in an automobile." Heinrich Inheim, "Messe und Ausstellung," Das Plakat 11 (1920): 292-293.

24. Lutz Michaelis, "Wie ensteht ein Werbetrickfilm," Die Reklame 20 (1927): 434.

25. Friedrich Irle, "Werbefilm und Erfolg," Die Reklame 20 (1927), 415.

26. I discuss this proliferation of mobile advertising projections and the interplay between fixed and mobile screens more generally in my article "Taking it to the Street: Screening the Advertising Film in the Weimar Republic," Screen 54.4 (2013): 463-479. For the term "Musterkoffer," see Arthur Lassally, "Filmreklame und Reklamefilm," Die Reklame 14 (1921): 425; Walther Drews, "Unterwegs. Der Vertreter mit dem Schmalfilmprojektor auf Reisen," Die Reklame 23 (1930): 576.

27. See Gunning, "The World as Object Lesson," 422.

28. “Die Leipziger Frühjahrsmesse," Die Reklame 13 (1920): 102.

29. See "Was bietet die Leipziger Messe dem Reklamefachmann?" Die Reklame 13 (1920): 273.

30. See "Reklamemesse," Die Reklame 13 (1920): 319.

31. Here too one could point to certain precursors, in particular the use of peephole type mutoscopes outfitted with several viewers. See Gunning, "The World as Object Lesson," 439.

32. Haidee Wasson, "The Other Small Screen: Moving Images at New York's World Fair 1939," Canadian Journal of Film Studies 21 (2012): 83.

33. "Die Leipziger Frühjahrsmesse," 102.

34. J. M. Merich, "Die III: Frankfurter Internationale Messe," Seidels Reklame 13 (1920): 284-285.

35. "Reklamemesse," 319.

36. J. von Dechend, "Der Film als Werbemittelauf der Messe," Die Reklame 16 (1923): 83.

37. Fritz Pauli, Rhythmus und Resonanz als ökonomisches Prinzip in der Reklame (Berlin: Verband Deutscher Reklamefachleute, 1926), 39. Pauli constantly resorts to the language of Fordism to describe the intended effects of rhythmical advertising: "[We] must imagine the sensory organs of the eye and the ear as continuously rotating and precisely measured cogwheels... External forces can affect the operation of these gears negatively or positively. If the impressions are uneven and irregular, the result will be the kind of grating and rattling one hears in an old car factory...But we can attain a smooth transference of energy if we adjust these gears to the correct tempo and the correct cogging" (37). For more on Pauli's system, see Cowan, Technology's Pulse, 132-138.

38. Advertising psychologists generally distinguished four operations of a successful advertisement: exciting the senses, capturing the attention, forging associations in memory, and motivating the consumer's will. A good summary can be found in Walther Moede, "Psychologie der Reklame," Die Reklame 13 (1920): 244-246.

39. See Cowan, Technology's Pulse, 139-166.

40. Gesolei was an acronym for Gesundheit (health) Sozialfürsorge (social welfare) and Leibesübung (bodily exercise). 
41. The name was an amalgamation of "planetarium" and the German term "planschen," which means "to splash about."

42. See Siegfried Mattl and Werner Schwarz, "Delirious Wien: Die Wiener Prater und die Assimilierung der Moderne," in Prater. Kino Welt: Der Wiener Prater und die Geschichte des Kinos, ed. Christian Dewald and Werner Schwarz (Vienna: Filmarchiv Austria, 2005), 87-101. For more on the connections between amusement parks and film culture in the German context, see especially Paul Dobryden, "The Institution of Pleasure: From Display to Environment at the Berlin Lunapark," Studies in European Cinema 10.3 (forthcoming 2014).

43. See Wilhelm Kreis, "'Gesolei' als künstlerische Gesamterscheinung," Die Reklame 19 (1926): 444.

44. On Schmarsow, see Georg Vasold, "Optique ou haptique: le rythme dans les études sur l'art au début du 20e siècle," Intermédialités, 16 (2010): 35-55, esp. 41.

45. See Gabrielle Genge, "Weibliche Leibesübung im Ehrenhof der Gesolei: Die Aktskulpturen von Arno Brecker, Ernst Gotschalk, Aristide Maillol und Bernd Sopher," in 1926-2002 / Ge So Lei. Kunst, Sport und Körper, ed. Hans Körner and Angela Stercken (Ostfildern-Ruit: Hatje Cantz Verlag, 2002), 141-46; Jürgen Wiener, "Rhythmus Körper Maschine: Aspekte der Achitekturtheorie des Wilhelm Kreis im Licht der Gesolei," in 1926-2002 / Ge So Lei, 168-69.

46. Kreis, 445.

47. See Angela Stercken, "Die Gesolei als Schaubild des Körpers: Sektionen, Überblick," in 1926-2002 / Ge So Lei, 111.

48. See Jennifer Dillion, Modernity, Sanitation and the Public Bath: Berlin, 1880-1930, as Archetype (Ph.D. Diss., Duke University, 2007), 26, 29.

49. Stercken, 110-116.

50. Marta Fraenkel, "Allgemeine organisatorische Fragen der wissenschaftlichen Abteilungen," in GE=SO=LEI: Grosse Ausstellung Düsseldorf 1926 für Gesundheitspflege, Soziale Fürsorge und Leibesübungen, vol. 2, ed. Arthur Schlossmann (Düsseldorf: Schwann, 1927), 409.

51. Fraenkel, 409. One American observer also reported seeing many films (presumably on portable devices) among the exhibition displays: "Pictures, models, dummy figures, images, dioramas, diapositives, rhenoscopes and films are freely used." Fielding H. Garrison, "The Gesolei at Düsseldorf," Bulletin of the New York Academy of Medicine 3:1 (January 1927): 2. The same writer goes on to explain: "Precisely the merit of the Gesolei is that it is designed to instruct the people by methods common to the picture writing of savages, the tavern-sign, the placard, the poster and the movies" (5).

52. On Lázsló's performances at the Gesolei, see Jörg Jewanski, "Eine neue KunstformDie Farblichtmusik Alexander Lázslós," in Farbe-Licht-Musik. Synästhesie und Farblichtmusik, ed. Jörg Jewanski and Natalia Sidler (Bern: Peter Lang, 2006), 221224; Cindy Keefer, "'Raumlichtmusik'-Early $20^{\text {th }}$-Century Abstract Cinema Immersive Environments," Leonardo Electronic Almanac 16:6-7 (2009). http://www.leonardo.info/LEA/CreativeData/CD_Keefer.pdf.

53. In his Cinema book, Gilles Deleuze, drawing on Bergson, describes modernist experiments in abstract cinema as an effort to "extract movement from the object moved or the mobility of movement itself." Gilles Deleuze, Cinéma I: L'Image-mouvement (Paris: Les Éditions de Minuit, 1983), 112.

54. And they also found an echo, of course, in Ruttmann's own heavy use of primary colours in both his Opus films and in advertising films such as Der Aufstieg.

55. In this respect, it also resembled other uses of film in exhibitions, such as the socalled "Theater der 4000" at the Kipho exhibition, where German films were shown in alternation. See "Quer durch die Kipho," Der Film 10.40 (1925): 23-24. 
56. See Walter Benjamin, "Das Kunstwerk im Zeitalter seiner technischen Reproduzierbarkeit 'Zweite Fassung,'" Gesammelte Schriften VII, ed. Rolf Tiedemann and Hermann Schweppenhäuser (Frankfurt am Main: Surhkamp, 1989): 357-358, 372.

57. See Jane Gaines, "Political Mimesis," in Jane Gaines and Michael Renov, eds., Collecting Visible Evidence (Minneapolis: University of Minnesota Press, 1999), 89.

58. On this point, see Thomas Elsaesser, "Harun Farocki: Filmmaker, Artist, Media Theorist," in Harun Farocki: Working on the Sight Lines, ed. Thomas Elsaesser (Amsterdam: Amsterdam University Press, 2004), 30.

MICHAEL COWAN is Associate Professor and William Dawson Research Chair in Film and Visual Culture at McGill University, where he also co-directs the Moving Image Research Laboratory. His work on film and visual culture has appeared in such journals as Screen, October, Art History, and Cinema Journal. 